\title{
KOMPATIBILITAS BATANG BAWAH DENGAN BATANG ATAS PADA METODE GRAFTING TANAMAN DURIAN (Durio zibethinus Murr)
}

\author{
Compatibility Of Rootstockwith Entresin Durian Grafting Method \\ (Durio zibethinus Murr) \\ Widyana Rahmatika, Fajar Setyawan. \\ Program Studi Agroekoteknologi, Fakultas Pertanian, Universitas Islam Kadiri \\ Email : ${ }^{1}$ widyanarahmatika@gmail.com, ${ }^{2}$ Fajar setyawan26@yahoo.com
}

\begin{abstract}
ABSTRAK
Durian menjadi salah satu buah yang memberikan nilai investasi tinggi bagi Indonesia. Namun, di Indonesia sendiri sedikit buah durian lokal yang bermutu tinggi yang dijual di pasaran. Salah satu faktor yang mempengaruhi ialah kurangnya penyediaan bibit varietas unggul yang ada. Oleh karena itu perlu cara perbanyakan durian yang dapat menghasilkan bibit varietas unggul untuk menghasilkan produksi tinggi.Beberapa teknik perbanyakan yang disarankan dalam budidaya durian secara vegetatif, salah satunya menggunakan metode grafting. Grafting adalah menggabungkan batang bawah dan batang atas dari tanaman yang berbeda menjadi tanaman baru. Tujuan penelitian ini adalahMenghasilkan bibit durian unggul lokal Kabupaten Kediri yang berpotensi tumbuh dengan baik dengan metode sambung (grafting) dan Mendapatkan informasi kompatibilitas batang bawah dengan batang atas dalam kaitan dengan sifat unggul bibit dan tanaman yang dihasilkan. Pada penelitian ini menggunakan Rancangan Acak Kelompok (RAK) factorial. Parameter pengamatan meliputi Hubungan jumlah daun dengan panjang tunas, persentase keberhasilan grafting, Kandungan Peotein bagian tanaman,dan titik pertautan sambungan.Dari hasil penelitian Perlakuan varietas kelud dengan panjang entres $10 \mathrm{~cm}$ memberikan persentase keberhasilan grafting durian yang lebih tinggi dibandingka dengan perlakuan lainya.

Kata Kunci: Durian, kompatibilitas, varietas
\end{abstract}

\begin{abstract}
Durian is one of the fruits that provides high investment value for Indonesia. However, in Indonesia there are few high-quality local durian fruits sold in the market. One of the influencing factors is the lack of supply of existing superior varieties of seeds. Therefore, it is necessary to propagate durian which can produce superior varieties of seeds to produce high production. Some propagation techniques are recommended in vegetative durian cultivation, one of which uses the grafting method. Grafting is combining rootstock and rootstock from different plants into new plants. The purpose of this study is to produce superior local durian seeds in Kediri Regency which have the potential to grow well with the grafting method and to obtain information on the compatibility of rootstock with stem top in relation to the superior properties of the seeds and plants produced. In this study using factorial Randomized Group Design (RBD). The parameters of the observations included the relationship of the number of leaves with the length of shoots, percentage of success of grafting, content of peotein of plant parts, and connection point of connection. From the results of the study the treatment of kelud varieties with entres length of $10 \mathrm{~cm}$ gave a higher percentage of success in durian grafting compared to the other treatments.
\end{abstract}


Keywords : Durian, compatibility, varieties

\section{PENDAHULUAN}

Tanaman durian merupakan tanaman asli di kawasan Asia Tenggara yang beriklim tropis seperti Indonesia, Thailand dan Malaysia (Ashari, 2006). Durian menjadi salah satu buah yang memberikan nilai investasi tinggi bagi Indonesia. Namun, di Indonesia sendiri sedikit buah durian lokal yang bermutu tinggi yang dijual di pasaran. Salah satu faktor yang mempengaruhi ialah kurangnya penyediaan bibit varietas unggul yang ada. Oleh karena itu perlu cara perbanyakan durian yang dapat menghasilkan bibit varietas unggul untuk menghasilkan produksi tinggi. Buah durian merupakan buah yang cukup diminati oleh masyarakat Indonesia. Permintaan pasar terhadap buah durian baik dari dalam negeri maupun luar negeri cukup tinggi, namun belum dapat dipenuhi oleh ketersediaan produksi buah durian.

Durian termasuk dalam genus Durio yang terdiri dari banyak species, hingga kini sudah diketahui sebanyak 30 spesies. Spesies Durio zibethinus terdiri dari ratusan varietas, baik yang telah dibudidayakan maupun yang masih hidup liar. Indonesia memiliki variasi iklim yang beragam. Kondisi agro-klimat yang beragam ini memberikan keunngulan tersendiri dalam budidaya tanaman durian. Perbedaan jenis serta lingkungan yang berbeda paling memperpanjang masa musim durian (Hariyono, 2013). Sebagian besar pohon durian yang ada di Indonesia saat ini berasal dari biji (secara generative). Menurut Uji (2005) tanaman akan menghasilkan buah membutuhkan waktu yang cukup lama pada kisaran 7 - 10 tahun. Sedangkan menurut Somari (2008) tanaman durian yang berasal dari biji akan berbuah pada umur 8-10 tahun, namun dengan perbanyakan vegetatif tanaman durian ini akan berbuah lebih cepat yaitu pada umur 4-5 tahun. Sebagian kecil sudah diusahakan dengan menggunakan bibit vegetative seperti okulasi, sambung atau cangkok. Penggunaan bibit vegetative akan menghasilkan buah bermutu tinggi (hasil dan kwalitas buah) (Hartman danKester,1978; Riady, 2016). Beberapa teknik perbanyakan yang disarankan dalam budidaya durian secara vegetatif, salah satunya menggunakan metode grafting. Grafting adalah menggabungkan batang bawah dan batang atas dari tanaman yang berbeda menjadi tanaman baru (Wudianto, 1988).

\section{METODOLOGI PENELITIAN}

Penelitian dilaksanakan di Desa Gadungan, Kecamatan Puncu, Kabupaten Kediri. Ketinggian tempat 224 meter di atas permukaan laut, jenis tanah aluvial dan $\mathrm{pH}$ 6,8, dilaksanakan pada mulai bulan Mei sampai bulan Juli 2017. Alat yang digunakan antara lain; gunting potong, pisau grafting,oven, sliding mikrotom, mikroskop, kamera digital, timbangan, bambu, paku, paranet, kantong plastik transparan, nescofilm, jangka sorong, meteran,cangkul, ayakan (22 mesh), papan nama, hand sprayer, gembor dan kawat tali. Sedangkan bahan yang digunakan antara lain: lima jenis batang bawah hasil seleksi 
penelitian II, dua varietas durian unggul lokal Kediri yaitu varietas Bokor dan varietas Kelud sebagai batang atas zat pewarna sfranin, larutan FAA, Cutek. Metode penelitian merupakan penelitian faktorial menggunakan Rancangan Acak Kelompok (RAK) dengan 3 kelompok. Faktor pertama adalah macam varietas yang terdiri dari : V1 = varietas Kelud dan V2 = varietas Bokor. Faktor kedua terdiri dari tiga level, yaitu: E1 = panjang batang atas $5 \mathrm{~cm}, \mathrm{E} 2$ = panjang batang atas $7,5 \mathrm{~cm}$ dan E3 = panjang batang atas $10 \mathrm{~cm}$. Variabel pengamatan meliputi: Hubungan jumlah daun dengan panjang tunas, persentase keberhasilan grafting, Kandungan Peotein bagian tanaman,dan titik pertautan sambungan. Data dianalisis menggunakan analisis ragam (uji F) pada taraf 5\%. Apabila berbeda nyata (F hitung > F Tabel 5\%), maka dilanjutkan dengan uji BNT pada Taraf 5\%.

\section{HASIL DAN PEMBAHASAN}

\section{Hubungan Antara Jumlah Daun dengan panjang tunas}

Berdasarkan hasil analisis ragam jumlah daun dan panjang Tunas tidak terjadi interaksi yang nyata, terdapat hubungan yang positif dan linear antara jumah daun dan panjang tunas. seperti yang terlihat pada Gambar1.

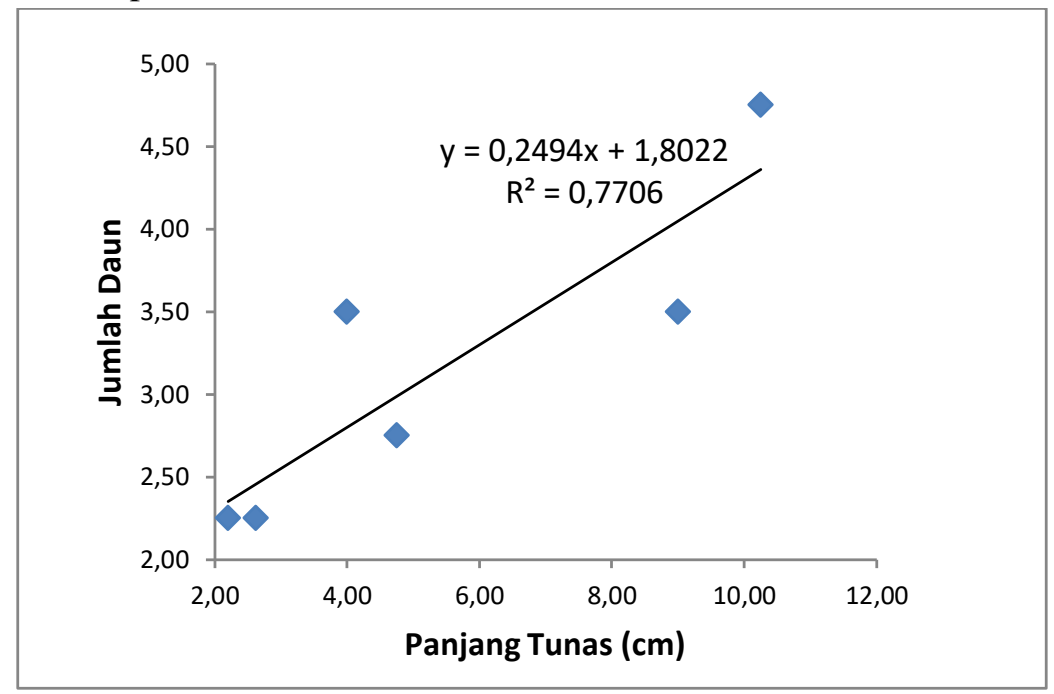

Gambar 1. Grafik Hubungan jumlah daun dengan panjang tunas $(\mathrm{cm})$

Hubungan antara jumlah daun dengan panjang tunas adalah ditunjukkan dengan persamaan regresi $\mathrm{Y}=0.2494 \mathrm{x}+1.8022$ Koefisien regresi adalah positif dengan koefisien determinasi $\left(\mathrm{R}^{2}\right)$ sebesar 0.7706 . Semakin bertambahnya panjang tunas maka semakin banyak jumlah daun yang muncul, daun merupakan salah satu organ tanaman yang sangat penting untuk membantu proses fotosintesis. Menurut Riodevriza (2010), pertumbuhan tunas yang baik akan mendapatkan pertumbuhan daun yang baik pula karena proses fotosintesis akan berjalan dengan baik sehingga tanaman dapat melakukan kegiatan metabolisme untuk perkembangan dan pertumbuhan tanaman tersebut. Menurut Hartman et 
al. (1990), didalam pertumbuhan tunas dapat dipengaruhi oleh kemampuan sel tanaman untuk melakukan elongasi atau perpanjangan. Penggunaan batang atas dari jenis yang berbeda memberikan hasil yang berbeda pada panjang tunas.Laksmi (2012) melaporkan bahwa genotip mempunyai pengaruh yang lebih bervariasi jika digunakan sebagai batang atas daripada batang bawah.

\section{Kandungan Protein (\%) daun Hasil Grafting}

Dari hasil pengamatan dan analisis besarnya kadar protein semakin panjang batang atas ( entres) maka semakin rendah kadar protein daunnya disebabkan pembentukan dan perkembangan organ tanaman berhubungan dengan ketersediaan air bagi tanaman. Hara yang berada dalam tanah diangkut melalui air yang terserap oleh tanaman melalui proses difusi osmosis yang terjadi. Semakin baik hara yang terserap oleh tanaman, maka ketersediaan bahan dasar bagi proses fotosintesis akan semakin baik pula. Fotosintesis yang berlangsung baik akan memicu peningkatan jumlah karbohidrat dan protein pada organ tubuh tanaman. Peningkatan jumlah karbohidrat dan protein sebagai akumulasi hasil proses fotosintesis yang akan berpengaruh pada berat basah tanaman (Fitrianah, 2012).

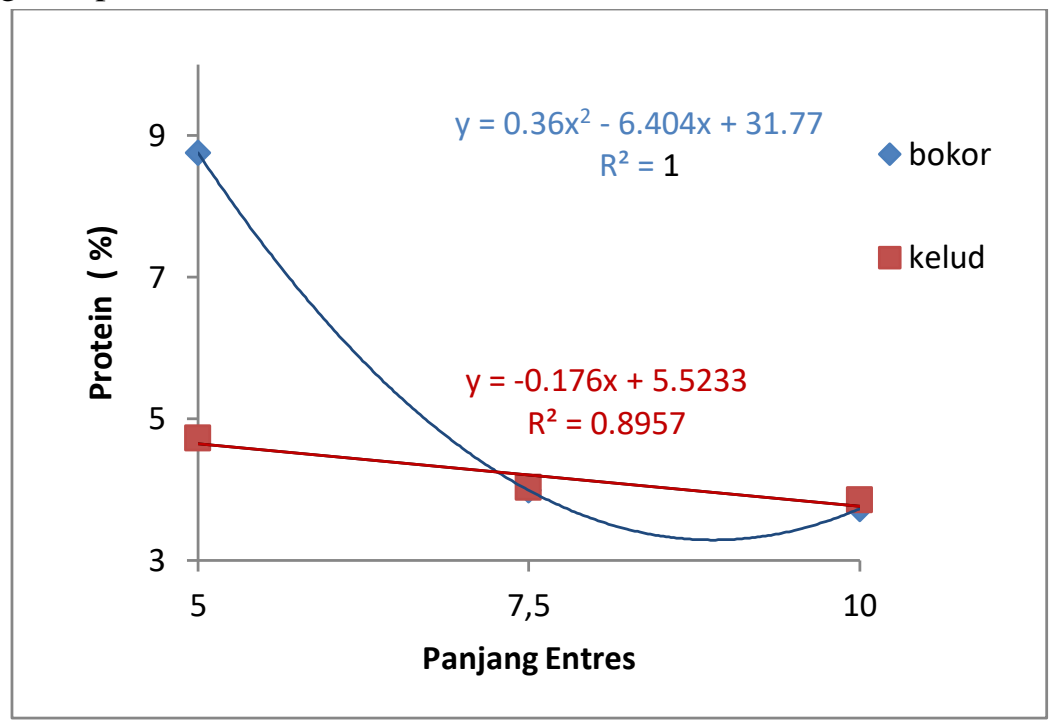

Gambar 2. Grafik Hubungan panjang Entres dengan kandungan Protein (\%)

Hubungan antara kandungan protein dengan panjang entres varietas bokor adalah ditunjukkan dengan persamaan regresi $\mathrm{Y}=0.36 \mathrm{x}^{2}-6.404 \mathrm{x}+31.77\left(\mathrm{R}^{2}=1\right)$ dengan hubungan kuadratik dimana semakin panjangnya batang atas (entres) maka kandungan proteinya semakin menurun dengan panjang entres $5 \mathrm{~cm}$ kandungan protein $8,75 \%$, panjang entres 7,5 cm kandungan protein 3,99\% dan panjang entres $10 \mathrm{~cm}$ kandungan protein 3,73\%. Sedangkan Hubungan antara kandungan protein dengan panjang entres varietas Kelud adalah ditunjukkan dengan persamaan regresi $\mathrm{Y}=-0.176 \mathrm{x}+5.5233\left(\mathrm{R}^{2}=0.8957\right)$ dengan koefisien regresi negatif dan linier dimana semakin panjang batang atas (entres) maka kandungan 
proteinya semakin menurun dengan panjang entres $5 \mathrm{~cm}$ kandungan protein $4,73 \%$, panjang entres 7,5 cm kandungan protein 4,03\% dan panjang entres $10 \mathrm{~cm}$ kandungan protein 3,85\% ( Gambar 2). Daun yang luas akan meningkatkan penangkapan cahaya, nitrat dan fosfat diperlukan sebagai bahan dasar penyusun protein dan pembentukan klorofil dalam proses fotosintesis. Fotosintesis merupakan proses perubahan zat anorganik menjadi zat organik. Semakin banyak $\mathrm{N}$ yang diserap oleh tanaman, maka semakin tinggi kandungan protein kasar pada tanaman. Lingga dan Marsono (2001) menyatakan bahwa fungsi pupuk nitrogen bagi tanaman adalah untuk merangsang pertumbuhan secara keseluruhan, yang meliputi batang, cabang, dan daun, dan berperan penting dalam pembentukan hijau daun yang sangat berguna dalam proses lainnya. Fungsi lainnya adalah membentuk protein, lemak, dan berbagai persenyawaan organik lainnya.

\section{Persentase Keberhasilan Grafting (\%)}

Keberhasilan grafting salah satunya dapat dilihat dari munculnya tunas baru pada batang atas saat umur 2-3 minggu setelah grafting. Hasil uji BNT 5\% perlakuan Macam Varietas dan panjang entres berbeda nyata pada keberhasilan grafting ( Gambar 3).

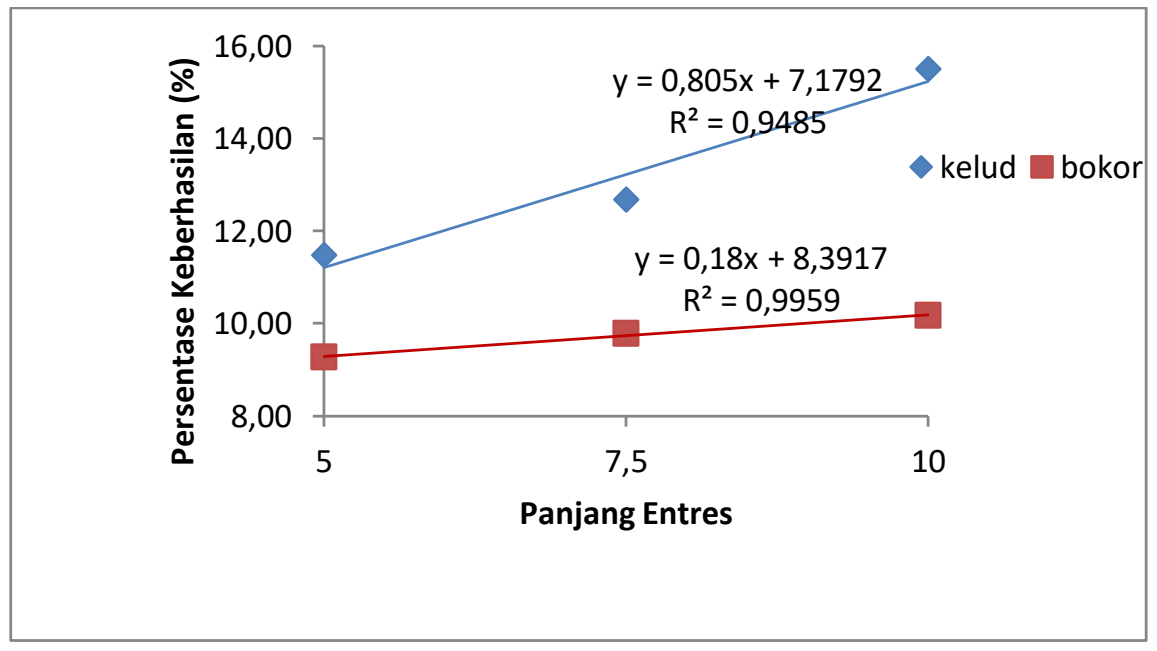

Gambar 3. Grafik Hubungan panjang Entres dengan Persentase Keberhasilan (\%)

Hubungan yang positif dan linear antara Panjang entres dan varietas bokor terhadap persentase keberhasilan. Hubungan antara panjang Entres dan varietas bokor terhadap persentase keberhasilan dengan persamaan regresi $\mathrm{Y}=0.18 \mathrm{x}+8.3917$, Koefisien regresi adalah positif dengan koefisien determinasi $\left(\mathrm{R}^{2}\right)$ sebesar 0.9959Sedangkan hubungan antara panjang Entres dan varietas kelud terhadap persentase keberhasilan dengan persamaan regresi $\mathrm{Y}=0.805 \mathrm{x}+7.1792,\left(\mathrm{R}^{2}\right)=0.9485$. Hubungan panjang Entres dan varietas bersifat linier yang dapat diartikan bahwa semakin panjang entres maka tingkat keberhasilan tanaman semakin tinggi( gambar 3). Menurut Roselina et al.,(2007) ketersediaan kambium yang rapat meningkatkan keberhasilan sambungan. Kambium batang bawah yang sudah melekat 
mempengaruhi persentase keberhasilan grafting. Holbrook et al. (2002) menyatakan bahwa kemampuan unsur hara dapat melewati bagian batang yang disambung, maka akan terjadi transport hormon yang berlangsung baik apabila terjadi kompatibilitas yang baik antara kedua batang yangdisambung.

\section{Pertautan Jaringan Grafting}

Pengamatan jaringan menggunakan mikroskop dengan perbesaran 40x memberikan hasil terbaik pada perlakuan varietas kelud dengan panjang entres $10 \mathrm{~cm}$, karena pada perlakuan tersebut jaringan sudah mulai menyatu dan bekas luka sayatan pada daerah penggabungan sudah mulai menghilang (Gambar 4).

Pertautan jaringan pada perlakuan sudah terlihat dengan berkurangnya bekas sayatan bekas sambungan, kambium antara kedua batang yang disambungkan sudah lebih menyatu yang dapat mempengaruhi proses pengangkutan unsur hara dan nutrisi keseluruh bagian tanaman menjadi lebih baik. Hartman et al. (1990) mengemukakan bahwa keberhasilan sambungan salah satunya dipengaruhi oleh kompatibilitas (kesesuaian) antara batang atas dan batang bawah untuk menyatukan diri. Saat pembentukan kalus, kerapatan antar komponen sambungan sangat penting, karena kekuatan sambungan terkait dengan hubungan antara batang atas dengan batang bawah (Seferough, et al. 2004). Keberhasilan sambungan sangat ditentukan oleh pertautan yang erat dari kambium kedua batang yang disambungkan. Hasil menggunakan batang atas kelud memberikan hasil pada keberhasilan grafting yang lebih tinggi dibandingkan Bokor. Menurut Riodevriza (2010) kambium mempunyai peranan yang penting dalam pembelahan dan pembentukan sel baru sehingga apabila kandungan cambium pada batang banyak maka keberhasilan sambungan meningkat. (Hartman et al., 1990) mengatakan Semakin banyak pertemuan kambium yang terjadi pada titik sambungan

akan meningkatkan keberhasilan sambungan. Menurut Handayani et al., (2013) pertautan sempurna pada hasil sambungan dapat ditandai dengan bekas sayatan pada sambungan yang sudah tidak terlihat dan xylem antara batang bawah dan batang atas bergabung membentuk xylem gabungan, sedangkan pada batang sambungan yang tidak terpautsempurna terlihat masih terdapat nekrotik dan bekas sayatan.Kelekatan jaringan pada hasil lebih sempurna ditunjukkan pada hasil Grafting yang lebih baik.

Gambar 4 : Jaringan Graffting pada varitas Bokor dan Kelud 


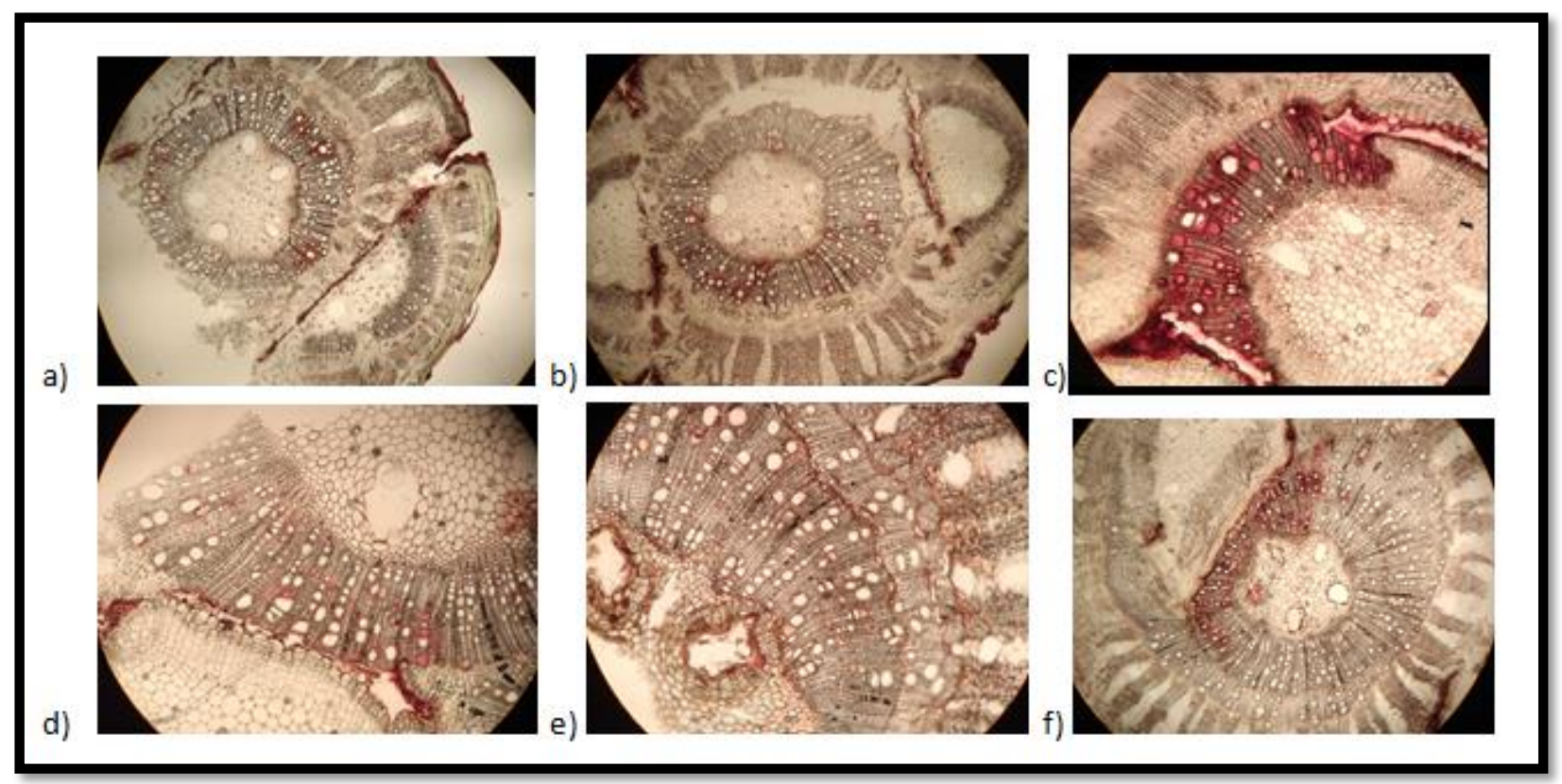

Keterangan : a) varietas Bokor + panjang batang atas $5 \mathrm{~cm}$, b) varietas Bokor + panjang batang atas $7,5 \mathrm{~cm}, \mathrm{c})$ varietas Bokor + panjang batang atas $10 \mathrm{~cm}$, d) varietas Kelud + panjang batang atas $5 \mathrm{~cm}$, e) varietas Kelud + panjang batang atas 7,5 cm, f)varietas Kelud + panjang batang atas $10 \mathrm{~cm}$

\section{KESIMPULAN}

Perlakuan varietas kelud dengan panjang entres $10 \mathrm{~cm}$ memberikan persentase keberhasilan grafting durian yang lebih tinggi dibandingka dengan perlakuan lainya. karena pada perlakuan tersebut jaringan sudah mulai menyatu dan bekas luka sayatan pada daerah penggabungan sudah mulai menghilang.

\section{DAFTAR PUSTAKA}

Ashari, S. 2006. Hortikultura Aspek Budidaya. UI Press. Jakarta. 490pp.

Fitrianah, Listin, Fatimah, Siti, Hidayati, Yunin. 2012.Pengaruh Komposisi Media Tanam Terhadap Pertumbuhan dan Kandungan Saponin pada Dua Varietas Tanaman Gendola (Basella sp.). Agrovivor. Vol: 5. No: 1. Hal: 9.

Handayani, S, P. Roedhy, Sobir, P. Agus, dan M. E. Tri. 2013. Effect of Rootstock and Shoot Types on In Vitro Mangosteen (Garcinia mangostana) Micrografting. Journal Agronomi Indonesia. 41(1):47-53.

Hanoto, W. 2000. Pengaruh batang bawah dan zat pengatur tumbuh terhadap tumbuhan penyambungan tanaman manggis (Garcinea mangostana L). Jurnal Agrotropikal. $5(1): 1-4$. 
Hariyono, D. 2013. Kajian masa pembungaan dan musim buah tanaman durian (Durio zibethinus Murr) lokal berbasis iklim diberbagai ketinggian tempat (Altitude). Disertasi program pasca sarjana, Fakultas Pertanian Universitas Brawijaya, Malang. 177 pp.

Hartman H.T and D.E. Kester. 1978. Plant propagation Principle and Practices. Prentice Hall INC Englewood. New York. p: 331.

Hartman, H. T., D. E. Kester, and F. T. Davies. 1990. Plant Propagation Principles and Practic. Fifth Edition. Prentice Hall International Inc., Englewood Cliffs. New Jersey.

Kostermans, A.J.G.H. 1958. The Genus Durio Adans. (Bombac). Reinwardtia 4(3): 47-153.

Lakitan B. 1996. Fisiologi pertumbuhan dan perkembangan tanaman. Raja Grafindo Persada, Jakarta.

Lingga, P. dan Marsono. 2001. Petunjuk Penggunaan Pupuk. Penebar Swadaya. Jakarta.

Riodevriza. 2010. Pengaruh Umur Pohon Induk terhadap Keberhasilan Stek dan Sambungan Shorea selanica BI. Skripsi. Departemen Silvikultur. Fakultas Kehutanan Institut Pertanian Bogor.Bogor.

Seferough G., F.E. Tekintas and Ozygit S. 2004. Determination Of Grafting Union Success In 0900 Ziraat And Stork Gold Cherry Cultivars On Gisela S And SL 64 Rootstocks. Journal Botany. 36(4):811-816.

Somari, S. 2008. Durian: Southeast Asia's King of Fruits. Chronic Horticulture. 48 (4):1922.

Supriadi, H dan N. Heryana. 2012. Sesuai batang bawah dan batang atas pada grafting jambu mete. Buletin RISTRI 3(2): 117-124.

Tambing, Y.2008. Kompatibilitas batang bawah nangka tahan kering dengan entris nangka asal Sulawesi tengah dengan cara sambung pucuk.Jurnal Agroland 15(2):95-100. 